\title{
LITERATURA E SOCIEDADE: AS PRÁTICAS DISCURSIVAS na obra Bom-Crioulo de Adolfo Caminha
}

\author{
Marcos S. S. de LIMA*
}

RESUMO: Este trabalho tem como objetivo apresentar uma análise discursiva, utilizando uma obra literária que traz temas extremamente atuais tais como o preconceito social e homofóbico. Trabalharemos em especial com os personagens Amaro (Bom-crioulo), Aleixo e D. Carolina, da obra Bom-Crioulo, produzida em 1895 por Adolfo Caminha, um dos principais autores brasileiros do Estilo Naturalista. Especificamente, evidenciaremos os discursos, as relações de poder e a subjetividade dos sujeitos representados pelos protagonistas. Tal abordagem tem como fundamentação teórica conceitos de Michel Pêcheux e, principalmente, de Michel Foucault acerca do discurso e do sujeito. Tentaremos mostrar como estes conceitos se relacionam e moldam a sociedade, como os sujeitos que fazem parte de uma determinada época da sociedade são construídos pelas práticas discursivas e pelo exercício das relações de poder, pois eles são sujeitos criados, fabricados, construídos pelas práticas discursivas, pelos poderes constituídos, transformando-se em sujeitos "úteis" à sociedade.

PALAVRAS-CHAVES: Discurso. Sujeito. Literatura. Sociedade.

\section{Uma breve introdução}

Sobre o que acontecia na sociedade no século XIX; Adolfo Caminha ${ }^{1}$ seguia um movimento de estilo Naturalista ${ }^{2}$ que surge no final desse século. Nessa

\footnotetext{
Secretaria Municipal de Educação de Canoas. Canoas - RS - Brasil. 92025370 - salmo.socram.ms@ gmail.com.

1 Adolfo Caminha (1867-1897) foi um escritor brasileiro. Um dos principais representantes do Naturalismo no Brasil.

2 Surgiu na França, na segunda metade do séc. XIX, chegando ao Brasil no final do século. Teve como tema principal a análise comportamental patológica do homem, de suas taras sexuais, de seu lado animalesco.
} 
época, desenvolvem-se as ciências humanas, o positivismo etc. A corrente literária adota teorias científicas como, por exemplo, a hereditariedade, a fim de explicar os problemas sociais. Nessa concepção, o homem é vítima das circunstâncias e é determinado pelo seu momento histórico e pelo meio em que vive. De acordo com Aburre, Pontara e Fadel (2003),

[...] os naturalistas viam, no comportamento do ser humano, traços de sua natureza animal e demonstravam a influência de tal natureza explorando temas como o homossexualismo, o incesto, o desequilíbrio que leva à loucura, criando personagens dominadas por seus instintos e desejos. A classe baixa foi, por excelência, o alvo das atenções naturalistas. A literatura de tese combinava bem com a apresentação das mazelas sociais, que se manifestavam de modo mais intenso entre as pessoas pobres e exploradas. (ABURRE; PONTARA; FADEL, 2003, p.83)

A obra Bom-Crioulo, de Adolfo Caminha (2003), apresenta características do estilo naturalista. Ela se passa na segunda metade do séc. XIX, no Rio de Janeiro, onde se destacam o espaço aberto, normalmente os dias são claros e quentes, no alto mar onde Amaro e Aleixo se conhecem; e o espaço fechado do quartinho que Amaro tem na Pousada de D. Carolina, localizado na Rua Misericórdia. Os dois lugares são descritos em seus aspectos mais degradantes e negativos, ressaltando a miséria daqueles que aí vivem. Narrado em $3^{a}$ pessoa, de característica onisciente, percebe-se que as inúmeras descrições que aparecem no romance, condizentes com o estilo naturalista que privilegia a observação meticulosa dos fatos, buscam não se confundir com a história, nem com as personagens.

A originalidade de Bom-Crioulo se manifesta no triângulo amoroso sobre o qual se sustenta. Tradicionalmente, um triângulo amoroso é composto por dois homens em luta por uma mulher, ou duas mulheres que disputam o mesmo homem. Em Bom-Crioulo, evidenciamos uma quebra neste estereótipo, o terceiro do triângulo, ou melhor, a terceira é uma mulher que atua com ações culturalmente masculinas, pois conquista Aleixo em vez de ser conquistada.

A abertura do romance se faz com uma detalhada descrição da corveta, local inicial da ação. Por meio de uma descrição minuciosa e da riqueza de detalhes que ajudam a compor o ambiente externo, percebe-se como o autor naturalista se debruça sobre o meio que terá um papel decisivo no comportamento das personagens. Conforme o trecho:

No entanto ela aí vinha — esquife agourento — singrando águas da pátria, quase lúgubre na sua marcha vagarosa; ela aí vinha, não já como uma enorme garça 
branca flechando a líquida planície, mas lenta, pesada, como se fora um grande morcego apocalíptico de asas abertas sobre o mar... (CAMINHA, 2003, p.14).

O ambiente de bordo é marcado pelo trabalho duro e por uma vida sem privacidade, o que possibilita a eclosão das mais diversas perversões. O ajuntamento de homens favorecia a promiscuidade entre seres que vivenciam a solidão da reclusão da vida no mar e que, sobretudo, sentiam a falta de liberdade, vítimas de um sistema duro e cruel, neste caso a vida na Marinha. Num segundo momento, a história se desloca para a terra, mais precisamente para um quarto na Rua da Misericórdia onde Amaro e Aleixo, após terem se conhecido no navio, vivem o ápice e o declínio de seu relacionamento:

O quarto era independente, com janela para os fundos da casa, espécie de sótão roído pelo cupim e tresandando a ácido fênico. Nele morrera de febre amarela um portuguesinho recém-chegado. Mas Bom-Crioulo, conquanto receasse as febres de mau-caráter, não se importou com isso, tratando de esquecer o caso e instalandose definitivamente (...) "O leito era uma cama de vento" já muito usada, sobre a qual o Bom-Crioulo tinha o zelo de estender, pela manhã, quando se levantava, um grosso cobertor encarnado "para ocultar as nódoas". (CAMINHA, 2003, p.54).

Os moradores da Rua Misericórdia eram brancos, mulatos e mestiços - o retrato fiel de nossa brasilidade - sempre pessoas exploradas, oprimidas pela sua condição social. Há a presença de negociantes portugueses em ascensão, como o açougueiro que sustenta D. Carolina, estes se aproveitam de algum modo, da miséria dessas pessoas. Desta maneira, o comportamento das personagens está condicionado pela pobreza do ambiente que as circunda. Caminha constrói com segurança e coerência o personagem Amaro, mulato dominado pela paixão homoafetiva, que o leva para caminhos desagradáveis até o ato criminoso.

Amaro é o protagonista, ex-escravo convocado à Marinha. Homem muito forte, com trinta anos de idade e que não conseguiu realizar-se sexualmente com as mulheres. Duas tentativas deram-lhe grande decepção e o deixaram frustrado. Só conseguiu consumar o ato com Aleixo. Apresenta certa profundidade psicológica, mas que é totalmente envolvido por sentimentos e instintos que o dominam, impedindo-o de perceber com clareza a situação conflituosa que vive. Os castigos físicos que lhe foram praticados transformaram-no em um homem resistente e lhe deram a energia de um ser altivo, vaidoso, digno, enfim, uma pessoa de amorpróprio.

Aleixo, também protagonista, grumete, belo rapaz de olhos azuis, que embarca no Sul. Tem quinze anos e mexe sexualmente com Amaro. Cede às investidas e 
caprichos do crioulo, mas quando aparece a ocasião o troca por uma mulher. Isso o leva ser assassinado por Amaro. Aleixo surge desde o princípio como o oposto de Amaro: branco, fisicamente fraco e pueril, subjugado pelas circunstâncias e por Amaro e D. Carolina. O ar de submissão de Aleixo vai se modificando ao longo da narrativa, isto é, suas experiências se transformam numa espécie de esperteza camaleônica. A ligação com Amaro lhe apresenta um novo mundo, bastante diferente daquele de sua origem, e que lhe propicia, acima de tudo, favores e proteção.

D. Carolina, antagonista, é a amiga e torna-se rival de Amaro. Ela é uma portuguesa que alugava quartos, na Rua Misericórdia, somente a pessoas de certa ordem, gente que não se fizesse de muito honrada e de muito boa, isso mesmo, rapazes de confiança, bons inquilinos, patrícios, amigos velhos. Desde o início, ela se revela uma mulher de negócios, cuja mercadoria era seu próprio corpo. Teve suas dificuldades, mas conseguiu se reerguer, observando como poderia lucrar com os outros, já que também lucravam com ela. No entanto, vive só.

Por fim, a narrativa do romance é simples e direta, mas não entrega o jogo facilmente, cria suspenses, vai e volta no tempo, de modo a dar a cada momento, a cada situação, a sua atualidade e a sua história, o seu desenvolvimento próprio. A intenção do romance se resume em acompanhar as personagens em sua movência de espaços e de suas práticas discursivas. Nele tudo caminha numa ordem inalterável até o fim, com uma supervalorização do instinto sobre os sentimentos, do animal sobre o homem, do irracional sobre o racional, do primitivo sobre o evoluído, e por fim, do amor sobre a razão.

É nesta narrativa que perceberemos que o sujeito, segundo Foucault (1984), tem a capacidade de se afirmar como ser singular - assumindo em termos morais a sua subjetividade que é uma atividade de libertação. Sem utopias, porém; a liberdade não quer dizer a independência de um livre arbítrio nem a libertação que tornaria o sujeito independente de qualquer coerção exterior ou interior como veremos no decorrer da análise. A liberdade não deixa de ser uma relação de poder. Ela articulase simultaneamente e de forma estreita tanto com a subjetividade como com o poder, materializando-se nas práticas discursivas.

\section{A análise discursiva da obra}

Analisando alguns elementos linguísticos da obra Bom-crioulo, observaremos o que se esconde por trás de determinados discursos. Segundo Brandão (2004), a partir de Foucault, o discurso é definido como um conjunto de enunciados (opondose ao conceito de frase, proposição, speech acts) que se constituem em uma mesma formação discursiva. Foucault (2009) chama de formação discursiva tudo que 
No caso em que se puder descrever, entre um certo número de enunciados, semelhante sistema de dispersão e, no caso em que entre os objetos, os tipos e enunciação, os conceitos, as escolhas temáticas, se puder definir uma regularidade (uma ordem, correlações, posições, funcionamentos, transformações) diremos, por convenção, que se trata de uma formação discursiva (FOUCAULT, 2009, p.43).

A partir da perspectiva de Foucault (2009), Michel Pêcheux, fundador da análise de discurso francesa, vai reelaborar o conceito de formação discursiva (FD). "Será da Arqueologia que Pêcheux extrairá o termo FD do qual a Análise do Discurso francesa se reapropriará, submetendo alguns elementos conceituais a um trabalho específico" (COURTINE, 2014, p.70). Portanto, para Pêcheux e Fuchs (2010) uma FD será tudo

[...] aquilo que, numa formação ideológica dada, isto é, a partir de uma posição dada numa conjuntura dada, determinada pelo estado da luta de classes, determina o que pode e deve ser dito (articulado sob a forma de uma arenga, de um sermão, de um panfleto, de uma exposição, de um programa, etc.). Isso equivale a afirmar que as palavras, expressões, proposições, etc., recebem seu sentido da formação discursiva na qual são produzidas [...] diremos que os indivíduos são "interpelados" em sujeitos-falantes (em sujeitos de seu discurso) pelas formações discursivas que representam "na linguagem" as formações ideológicas que lhes correspondem. (PÊCHEUX; FUCHS, 2010, p.160-161).

Assim, para Foucault (2009), a FD é um conjunto de enunciados que não estão reduzidos ao sistema da língua, mas que também não se submetem à continuidade histórica nem estão subordinados a uma mesma regulação e dispersão no modo ideológico, científico, de teorias etc. Para Pêcheux (2008), tal conceito parte do prisma do marxismo de Althusser, isto quer dizer que a FD enfatiza aquilo que deve e pode ser dito e se situa no espaço da luta de classes.

Foucault (2009) diz que um enunciado possui uma materialidade, uma substância, em um lugar, em uma data, e mais do que isso, possui uma função enunciativa. As sequências linguísticas do corpus para que sejam consideradas e analisadas como uma função enunciativa, sua existência material faz-se necessária, isto é, o enunciado será sempre mostrado em uma espessura material que o constitui. Gregolin (2006) afirma que Foucault procura compreender as ocorrências do discurso, isto é, o surgimento dos enunciados possibilitando o estabelecimento e a estabilização de determinados objetos em nossa cultura. $\mathrm{O}$ projeto de uma descrição de fatos discursivos constitui-se como um sistema finito 
e efetivamente limitado das sequências que tenham sido formuladas entendendo o enunciado em sua peculiaridade de ocorrências, em sua irrupção histórica, já que ele "é sempre acontecimentos que nem a língua, nem o sentido podem esgotar inteiramente"(Foucault, 2009, p.88). Por outro lado, sua emergência pressupõe articulações com outros enunciados e é necessário descrever esses jogos de relações. Foucault (2009, p. 88) vê, portanto, no enunciado uma articulação dialética entre a singularidade e repetição: "de um lado, ele é um gesto; de outro, liga-se a uma memória, tem uma materialidade; é o único mais aberto à repetição e se liga ao passado e ao futuro" e que Pêcheux e Fuchs (2010), inicialmente, em sua teoria sobre o discurso vai chamar de efeito parafrástico.

Para Pêchuex (2010), o estudo do discurso, consequentemente para a análise do discurso (AD) francesa, inscreve-se num terreno em que intervêm questões teóricas relativas à língua, ao sujeito e à ideologia. Tendo como base o materialismo histórico, a $\mathrm{AD}$ concebe o discurso como uma manifestação, uma materialização da ideologia decorrente da maneira de organizar as formas de produção social. A ideologia, nesse campo teórico-prático, surge como efeito da relação necessária do sujeito com a língua e com a história para que a signifique.

Conforme Pêcheux (2010), o sujeito tem uma marca no espaço e no tempo, sendo essencialmente histórico. Dito de outra forma, quando o sujeito fala, ele fala de um determinado local e de um determinado tempo. O autor vai unir a concepção de sujeito não somente histórico, mas também fundamentalmente ideológico. Ele rompe com as ideias de um sujeito uno, livre, que vai ser caracterizado pela consciência (sem inconsciente, sem ideologia) e tomado como origem do que diz. O sujeito, para a $\mathrm{AD}$, não é considerado como um ser orgânico, um ser de pele e osso, um ser empírico, um falante, locutor ou mesmo um emissor, mas sim ele é constituído pela relação que possui com o outro.

Pêcheux (2010) define o sujeito como sendo clivado, não uno; um sujeito assujeitado, não livre, não estando na origem do discurso. Denuncia, nessa ideia, a ilusão do sujeito falante. $\mathrm{AAD}$ critica a teoria da subjetividade que reflete a ilusão do sujeito onipotente, intencional, dono do que pensa e diz. A compreensão do sujeito como centrado, consciente, não ideológico perde sua centralidade.

Logo, a $\mathrm{AD}$ francesa envolve uma análise contextual das práticas discursivas. O contexto histórico-político-social, em que os sujeitos estão inseridos, determina diretamente as ideologias presentes em um discurso. Assim, o discurso é uma criação da lingua(gem) atrelada ao contexto social onde aquele é desenvolvido. Sendo este objeto primordial da AD, o discurso, para Pêcheux (2008), considera a linguagem em ação, os efeitos engendrados através do seu uso e o sentido social que se constrói, e este sentido encontra-se sempre aberto à interpretação. Como afirma Pêcheux (2008), 
Todo enunciado é intrinsecamente suscetível de tornar-se outro, diferente de si mesmo, se deslocar discursivamente de seu sentido para derivar para outro [...]. Todo enunciado, toda sequência de enunciados é, pois, linguisticamente descritível como uma série (léxico-sintaticamente determinada) de pontos de deriva possíveis, oferecendo lugar a interpretação. É nesse espaço que pretende trabalhar a análise de discurso. (PECHEUX, 2008, p. 53).

A partir daí, tomamos como leitura os discursos que se encontram na obra de Caminha (2003), a fim de encontrar elementos linguísticos que fazem parte de discursos específicos e que possuem léxicos particulares de uma FD, isto é, de saberes aos quais os sujeitos se filiam. $\mathrm{O}$ narrador do romance a cada enunciado pronunciado vai nos encaminhando a uma prática discursiva que é responsável por formar um espaço comum que abordará temáticas a respeito do preconceito social e, principalmente, do homossexual. Ele é responsável em descrever todo o cenário hostil e preconceituoso em que os personagens estão inseridos, e descrever as ações destes, levando-nos para um tempo e lugar que possui discursos que são determinados pelos saberes nos quais se inscrevem. Cada enunciado produzido pelo narrador acerca do cenário ou dos personagens, conduz o leitor a um discurso de que percebemos ser de negação, de subordinação, de seres que vivem num ambiente, onde a sobrevivência se faz através do proibido e da submissão. Os sujeitos são aprisionados em um sistema disciplinar onde seus dizeres são controlados e vigiados, remetendo a um discurso de submissão, escravidão, opressão, marginalização, etc. A saber,

Silêncio absoluto nas fileiras da marinhagem. Cada olhar tinha um brilho especial de indiscreta curiosidade. Um frêmito de instintiva covardia, como uma corrente elétrica, vinha à face de toda aquela gente abespinhada ali assim perante um só homem, cuja a palavra trazia sempre o cunho áspera da disciplina. Era um respeito profundo chegando às raias da subserviência animal que se agacha para receber o castigo, justo ou injusto, seja ele qual for. (CAMINHA, 2003, p.16)

- Corja! Regougou o comandante brandindo a luva. Não se compenetram de seus deveres, não respeitam a autoridade! Hei de ensiná-los: ou racho-os! (CAMINHA, 2003, p.19).

Nada é dito por acaso, sempre o que dizemos tem uma intenção, um valor cultural, social e/ou político, o que significa dizer que ao escrever o romance, Adolfo Caminha (2003) está querendo nos dizer algo, sua prática discursiva tem uma intencionalidade produzindo um efeito de sentido em seu interlocutor, leitor. $\mathrm{O}$ autor, ao criar o espaço militar e as ações dos personagens, revela o que acontece dentro 
desse espaço hierárquico que ninguém, além dos sujeitos que dali fazem parte, podem saber, e que muitas vezes, quando é externado sofrem severas punições.

Trazendo elementos linguísticos que remetem a um discurso homoerótico, podemos perceber que os enunciados dos personagens não são explícitos, isto é, eles não falam claramente acerca do envolvimento de Amaro e Aleixo ou das feições que alguns oficiais têm com seus subordinados, porque, conforme Pêcheux (2010), ao se inscrever em determinada FD, nem todo sujeito pode e deve dizer o que pensa. Tanto o narrador quanto alguns personagens possuem enunciados que nos encaminham para um discurso proibido, ou seja, do relacionamento entre seres iguais, rodeados por hostilidade, preconceito, negação do desejo, proibição e submissão. Como mostram os excetos,

[...] o comandante Albuquerque recompensava os serviços de sua gente, não se negava a promover os seus afeiçoados. Isso de se dizer que preferia um sexo a outro nas relações amorosas podia ser uma calunia como tantas que se inventam por aí... [...] Bom-Crioulo, não tinha nada que ver com isso. Era uma questão à parte, que diabo! Ninguém está livre de um vício. (CAMINHA, 2003, p.29)

Nas horas de folga, no serviço [...] ninguém the tirava da imaginação o petiz: era uma perseguição de todos os instantes, uma ideia fixa e tenaz, um relaxamento da vontade irresistivelmente dominada pelo desejo de unir-se ao marujo (Aleixo) como se ele fora de outro sexo, de possuí-lo, de tê-lo junto a si, de amá-lo, de gozá-lo! [...]

E agora, como é que não tinha forças para resistir aos impulsos do sangue? Como é que se compreendia o amor, o desejo de posse animal entre duas pessoas do mesmo sexo, entre dois homens? (CAMINHA, 2003, p.34)

Bom-Crioulo sentia uma febre extraordinária de erotismo, um delírio invencível de gozo pederasta... agora compreendia nitidamente que só no homem, no próprio homem, ele podia encontrar aquilo que debalde procurara nas mulheres.

[...] havia exemplo ali mesmo a bordo, para não falar em certo oficial de quem se diziam coisas medonhas no tocante à vida particular. Se os brancos faziam, quanto mais os negros é que nem todos têm força para resistir: a natureza pode mais que a vontade humana... (CAMINHA, 2003, p.46)

Estava satisfeita a vontade de Bom-Crioulo, Aleixo surgia-lhe agora em plena e exuberante nudez (...) Sodoma ressurgia agora numa triste e desolada baiuca da Rua da Misericórdia (...). (CAMINHA, 2003, p.56)

Observando os elementos que nos levam a um sistema hierárquico, objetivamos encaminhar o/a leitor/a à uma relação de poder que está representada 
na instituição militar, que é a Marinha. Ela é o que Foucault (1996) chama de um poder cujo seu exercício encontra-se nos sujeitos envolvidos por ela e nela, enquanto isso, os discursos que se referem aos subordinados são sempre de tom pejorativo, tais como "a marinhagem, analfabeta e rude (...)" (Caminha, p.15). Na instituição militar há uma relação de poder hierárquico bastante evidente, em que o militar de uma patente mais alta não pode ser desrespeitado, questionado, desobedecido; e que é detentor de poder e possui um saber que não pode ser contrariado, pois o subordinado sofrerá as sansões previstas e será punido severamente. Temos aí, a constituição de práticas discursivas em que determinados sujeitos podem e devem dizer algo e outros sujeitos que não podem e não devem dizer nada, ou seja, temos sujeitos antagônicos inscritos em uma mesma FD.

Os personagens representam bem as relações de poder; mas ainda, essas relações entre eles ratificam o que Foucault (1996) mostra acerca do poder. Para ele, não existe uma teoria geral do poder, o que significar dizer que suas análises não consideram o poder como uma realidade que possua uma natureza, uma essência que ele procuraria definir por suas características universais. Não existe algo unitário ou global chamado poder, mas unicamente formas díspares, heterogêneas, em constante transformação. Logo, o poder não é um objeto natural, uma coisa; mas sim, uma prática social e, como tal, constituída historicamente.

Este poder intervém materialmente, atingindo a realidade mais concreta dos sujeitos (o seu próprio corpo) e se situa ao nível do próprio corpo social, e não acima dele, penetrando na vida cotidiana e por isso podendo ser caracterizado como micropoder ou subpoder. O que o filósofo chamou de microfísica do poder significa, tanto um deslocamento do espaço da análise quanto o nível em que esta se efetua. Dois aspectos intimamente ligados, na medida em que a consideração do poder em suas extremidades, a atenção as suas formas locais, a seus últimos lineamentos tem como correlata a investigação dos procedimentos técnicos de poder que realizam um controle detalhado, minucioso do corpo (gestos, atitudes, comportamentos, hábitos).

Então, o poder não é um objeto, uma coisa que podemos pegar ou apalpar, algo tácito, mas uma relação entre sujeitos que exercem uma multiplicidade de forças. Seja entre os marinheiros entre si, entre estes e os oficiais; seja entre os oficiais e seu comandante; seja entre o comandante e a instituição militar; ou entre ela e o Estado, ou seja, uma teia de relações de poder.

Constatamos assim os princípios de controle do discurso de que Foucault (1996) menciona em sua obra A ordem do discurso. Os personagens representam sujeitos que pronunciam discursos que são rodeados por regularidades que envolvem tais princípios. A marinha representa uma instituição disciplinar com meios de controlar, organizar e gerenciar os discursos dos sujeitos que nela estão inseridos, 
ou melhor, exerce um procedimento de interdição na qual os marinheiros têm que medir, modalizar o que vão dizer e/ou fazer, pois seus dizeres podem acarretar em severas punições.

Ora, aconteceu que (...) Herculano foi surpreendido, por outro marinheiro, a praticar uma ação feia e deprimente do caráter humano. Tinham-no encontrado sozinho, junta à amurada, em pé, a mexer com o braço numa posição torpe, cometendo, contra si próprio, o mais vergonhoso dos atentados.

(...) acabava de cometer um verdadeiro crime não previsto nos códigos, um crime de lesa-natureza, derramando inutilmente, no convés seco e inútil, a seiva geradora do homem. (CAMINHA, 2003, p. 19).

O homem não pode se masturbar, não pode ter relações sexuais para fins de seu prazer, a não ser para procriação; e, principalmente, não pode ter relações com um ser do mesmo sexo, caso contrário será castigado pela vontade divina. Assim, percebemos que o personagem a ser punido sente uma culpa em decorrência da efetivação dos prazeres corporais, esperando, desta forma, sua penalização. $\mathrm{O}$ trecho mostra um discurso cristão que é, até hoje, bastante utilizado. Um discurso que confirma o que Foucault (1996) esboça sobre o medo do discurso. Este é ao mesmo tempo respeitado e temeroso, surgindo daí sistemas de controle instituídos de maneira a dominar e proliferar. O personagem Bom-Crioulo, durante todo o romance, também sofre essa influência do discurso cristão, pois ao sentir um sentimento forte pelo grumete, o narrador tece discursos geradores de preconceitos acerca das ações daquele. Os enunciados abaixo confirmam essa tese:

(Aleixo) começava a sentir no próprio sangue impulsos nunca experimentados, uma como vontade ingênita de ceder aos caprichos do negro, de abandonar-se lhe para o que ele quisesse - uma vaga distensão dos nervos, um prurido de passividade...

- Ande logo! Murmurou apressadamente, voltando-se.

E consumou-se o delito contra a natureza. (CAMINHA, 2003, p.43)

Nunca se apercebera de semelhante anomalia, nunca em sua (Amaro) vida tivera a lembrança de perscrutar suas tendências em matéria de sexualidade. As mulheres o desarmavam para os combates do amor, é certo, mas também não concebia, por forma alguma, esse comercio grosseiro entre indivíduos do mesmo sexo; entretanto, quem diria! o fato passava-se agora consigo próprio, sem premeditação, inesperadamente. E o mais interessante é que "aquilo" ameaçava ir longe, para mal de seus pecados... Não havia jeito, senão ter paciência, uma vez que a "natureza" lhe impunha esse castigo. (CAMINHA, 2003, p.46). 
Outra instituição bastante forte em seu modo de controlar o discurso é a sociedade com suas regras e moralidade. Ela, talvez, abarque todos os princípios de controle do discurso, porque é nela que se convergem tais procedimentos de controle. É nela que vemos as manifestações do princípio da segregação e interdição. $\mathrm{Na}$ obra, os marinheiros e suas patentes, cada um sendo ou tendo seu subordinado; e exercendo a relação de poder entre eles; na rua Misericórdia, onde existem brancos, mulatos e mestiços (pessoas miseráveis), encontra-se sujeitos que sofrem o exercício desses procedimentos de controle do discurso.

A instituição militar exerce uma vontade de verdade, isto é, há um comandante que não pode ser contrariado ou questionado, pois seus discursos passam por verdadeiros, em virtude, é claro, de sua patente ser a mais elevada dentro do navio. Logo concluímos que os princípios de controles do discurso estão em todo o canto da obra de Caminha.

$\mathrm{Na}$ leitura do personagem de Amaro, podemos averiguar explicitamente um dos três procedimentos de controle do discurso do qual Foucault (1996) fala em $A$ ordem do discurso. O ritual que é responsável pela definição da qualificação, dos comportamentos, das circunstâncias que devem possuir os sujeitos que falam e que são falados, e todo o conjunto de signos que devem acompanhar o discurso, fixando a eficácia suposta ou imposta das palavras, seu efeito sobre aqueles aos quais se dirigem, os limites de seu valor de coerção.

Alguns personagens, que fazem parte tanto do universo militar quanto dos moradores da rua Misericórdia, estão sendo controlados pelo princípio de controle das sociedades de discurso, isto é, esse controle possui a função de conservar ou produzir discursos específicos. Práticas discursivas que os sujeitos excluídos e /ou dominados não podem falar/fazer o que querem, estando aprisionados em uma rede de procedimentos de controle do discurso. Por exemplo, os marinheiros ao serem punidos tentam argumentar, persuadir, e até implorar aos seus superiores, a fim de não sofrem as chibatadas.

A doutrina é um princípio de controle do discurso que tem a função inversa das sociedades de discurso, ela objetiva discursos restritos a certas FD's, ou seja, nem todos os sujeitos podem utilizar certos enunciados em todos os locais, tal como o relacionamento de Amaro com Aleixo, pois vão tentar construir um sentimento, relacionamento que irá de encontro com as regras sociais, em que não podem exporse em todos os momentos e locais. O romance está repleto de discursos que nos levam à uma ideia de algo que não pode vir à tona ou que não pode ser revelado ou dito. $\mathrm{O}$ excerto a seguir descreve bem esse princípio da doutrina:

Nesse dia Priapo (Bom Crioulo) jurou chegar ao cabo da luta. Ou vencer ou morrer! - ou o pequeno se resolvia ou estavam desfeitas as relações. Era preciso resolver 'aquilo'. 
— aquilo quê? Perguntou o rapazinho muito admirado.

— nada; o que eu quero é que não te zangues comigo. (CAMINHA, 2003, p. 41)

Bom-Crioulo ao avistar pela primeira vez o grumete, sente por este uma sensação incontrolável, nascendo um desejo de possuí-lo. A partir desse sentimento que se fortalece no decorrer do romance, Amaro passa a construir um conhecimento, enxergando o mundo a sua volta com outros olhos. Olhos que se abrem a um desejo de possessão, de estar a todo o momento com Aleixo, pois este, com todo seu erotismo, com toda sua beleza andrógena, hipnotiza tanto Amaro quanto D. Carolina. Aí, percebemos um sujeito submisso a seus instintos, esses que na sociedade da época são ditos imorais. No romance, a moral quase religiosa e imposta por esta sociedade não se destaca à questão dos desejos de um homem por outro, comparado a um habitat de animais em meio a natureza, os desejos acontecem independente do julgamento dos outros, reforçando a ideia do instinto como orientador do comportamento humano em tom amoral. Os excertos descrevem muito bem os sentimentos de Amaro e D. Carolina pelo grumetizinho, o bonitinho.

Esse movimento indefinível que acomete ao mesmo tempo duas naturezas de sexos contrários, determinando o desejo fisiológico da posse mútua, essa atração animal que faz o homem escravo da mulher e que em todas as espécies impulsiona o macho para a fêmea, sentiu-a Bom-Crioulo irresistivelmente ao cruzar a vista pela primeira vez com o grumetizinho. Nunca experimentara semelhante impressão, desde que se conhecia! Entretanto, o certo é que o pequeno, uma criança de quinze anos, abalara toda a sua alma, dominando-a, escravizando-a logo, naquele mesmo instante, como a força magnética de um imã.

(D. Carolina) Há dias metera-se-lhe na cabeça uma extravagância: conquistar o Aleixo, o bonitinho, tomá-lo para si, tê-lo como amantezinho do seu coração avelhentado e gasto, amigar-se com ele, secretamente, dando-lhe tudo quanto fosse preciso: roupa, calçado, almoço e jantar nos dias de folga — dando-lhe tudo enfim. [...] Aleixo remoçava-a como um elixir estranho, milagrosamente afrodisíaco. Sentia-se outra depois que se metera com o pequerrucho: retesavamse-lhe os nervos, abria-se-lhe o apetite, entrava n'alma uma extraordinária alegria de noiva em plena lua-de-mel, toda ela vibrava numa festiva exuberância de vida. (CAMINHA, 2003, p.48).

Percebemos em ambos os excertos que o discurso inserido é de seres dominados (Amaro e D. Carolina) e dominante (Aleixo), no qual este possui uma beleza que impulsiona de maneira irracional, ou melhor, abre o apetite incontrolável dos dominados. O amor entre Amaro e Aleixo é uma repetição das relações entre os 
gregos que ocorria na Grécia antiguidade. Segundo Foucault (1984), neste período, era permitida e incentivada a relação entre sujeitos do mesmo sexo, tendo em vista que para a sociedade grega era importante que um rapaz mais novo tivesse suas experiências de vida iniciada com um homem mais velho, com a finalidade de fortalecer a mesma sociedade. O narrador nos leva a esse pensamento, pois a obra possui inúmeros enunciados a esse discurso, tal como quando Bom-Crioulo pegou o grumete experimentando um cigarro, aquele quase o fez chorar ao pegá-lo, ou no momento em que Amaro se gaba de conhecer o mundo, prometendo cuidar de Aleixo.

Aleixo é um rapaz bonito e, principalmente, jovem que se incorpora na Marinha; não conhece nada da vida, mas é com Amaro que conhece os prazeres carnais. Contudo, quando este se vê afastado do grumete por motivo de enfermidade. D. Carolina se aproveita para se relacionar com Aleixo, do qual passa a gostar. Por fim, toda a sociedade tem sistemas que são responsáveis em gerenciar, cuidar do comportamento, da vida, da saúde dos sujeitos sociais. Estes sistemas institucionais fazem parte do controle de princípio das apropriações sociais do discurso que estão representadas na obra pela Marinha e pelo hospital onde Amaro está como enfermo.

Porém, essa rede de sistemas que se preocupa com o comportamento, a saúde dos sujeitos sociais, pode ser considerada como ponto positivo, isto é, quando Foucault (1999) esboça sobre a positividade do poder, ele define que este não é somente negativo, mas sim também positivo; o que se acarreta em uma produtividade, uma transformação e eficiência. A ideia básica de Foucault é de elucidar que as relações de poder não se passam fundamentalmente nem ao nível do direito, nem da violência; nem são basicamente contratuais nem unicamente representativas. Em seus estudos sobre repressão, nos livros Vigiar e Punir (1999) e $A$ vontade de Saber(1988), ele quis demonstrar que é falso definir o poder como algo que diz não, que impõe limite, que castiga. Há uma concepção negativa, que identifica o poder com o Estado e o considera essencialmente como aparelho repressivo, no sentido em que seu modo básico de intervenção sobre os cidadãos se daria em forma de violência, coerção, opressão; ele opõe, ou acrescenta uma concepção positiva que pretende dissociar os termos dominação e repressão.

Não se conceitua o poder somente como repressivo. O que lhe interessa não é expulsar os homens da vida social, impedir o exercício de suas atividades, e sim gerir a vida deles, controlar as ações para que seja possível e viável usá-los ao máximo, aproveitando suas potencialidades e utilizando um conjunto de aperfeiçoamento gradual e contínuo dessas capacidades. Objetivo ao mesmo tempo econômico e político: aumento do efeito de seu trabalho, isto é, tornar homens forças de trabalho dando-lhes uma utilidade econômica máxima; diminuição de sua capacidade de 
revolta, de resistência, de luta, de insurreição contra as ordens do poder, neutralização dos efeitos de contra-poder, isto é, tornar homens dóceis politicamente. Portanto, aumentar a utilidade econômica e diminuir os inconvenientes, os perigos políticos; aumentar a força econômica e diminuir a força política.

Dado isso, vemos que o poder tem como objetivo aprimorar o sujeito através do corpo com a utilização de tecnologias de coerção. Na obra, Amaro e Aleixo são marinheiros e, acima de tudo, como tal se comportam, favorecendo a anulação das diferenças étnicas, que se dá não pela ascensão do negro fugido, mas à condição de prisioneiros do mesmo sistema (Marinha), a fim de moldá-los, adestrá-los, instruílos, discipliná-los. Os personagens não serão expulsos do meio social, não serão mutilados, aniquilados, mas controlados, com a finalidade de serem gerenciados em suas ações. Com isso, será possível utilizá-los ao máximo, aproveitando suas capacidades, potencialidades, aperfeiçoando gradual e continuamente seus corpos, tanto física quanto mentalmente. É assim que a Marinha, o hospital, enfim, a sociedade como um todo com seus sistemas institucionais zelou por seus sujeitos, para que eles possam ter uma vida saudável e, principalmente, uma vida útil ao Estado.

Mas quando existem sujeitos que seguem um caminho que vai de encontro aos interesses do Poder, ou seja, quando há resistência a essas técnicas, a esses domínios de controle, os sujeitos acabam por serem esmagados pelas forças coercivas. É o que aconteceu com os moradores da rua Misericórdia, pois eles são os excluídos, tendo em vista que não se comportaram devidamente, ou melhor, como a sociedade impôs que fizessem.

D. Carolina era uma portuguesa que alugava quartos na Rua da Misericórdia somente a pessoas de "certa ordem" (...)Não fazia questão de cor e tampouco se importava com a classe ou profissão do sujeito. Marinheiro, soldado, embarcadiço, caixeiro de venda, tudo era a mesmíssima coisa (...) (CAMINHA, 2003, p.50)

Quase nenhum movimento ainda na Rua da Misericórdia sujeitos malvestidos, operários e ganhadores, desciam com um ar miserável e bisonho de ovelhas mansas que seguem fatalmente, num passo ronceiro, numa lentidão arrastada, numa quase indolência de eunucos. (CAMINHA, 2003, p.113).

Por fim, encontramos práticas discursivas que regulam, controlam, gerenciam as atitudes dos personagens, inseridos em um espaço hostil e preconceituoso e que, às vezes, apresentam ações de rebelia inconsciente contra o(s) sistema(s) do qual fazem parte; e quando eles resistem a esse(s) sistema(s) sofrem com sua ousadia de rebelar-se contra está ideologia que os domina. 


\section{Concluindo}

A partir desta breve análise, entendemos que o sujeito não é aquilo que gostaria de ser, mas aquilo que o sistema, a sociedade determina que ele seja, por meio das FD's as quais eles se filiam. Isso nos mostrou que somos o resultado de uma fabricação, através dos discursos do poder, dos sistemas institucionais que são responsáveis por tais práticas discursivas. Estas com determinadas intenções nos constituem em sujeitos. É nesse sentido que tanto Foucault quanto Pêcheux, nos levam à conclusão de que cada um de nós enquanto sujeito, homem inserido em uma sociedade e por ela estruturado, fazemos não o que queremos ou gostaríamos, mas aquilo que podemos e/ou devemos; aquilo que nos cabe na posição de sujeitos que ocupamos um determinado lugar e tempo social, aprisionados por determinada ideologia.

É assim que procuramos, por meio da literatura, mais especificamente do romance Bom-Crioulo, ilustrar que o personagem de Amaro é um sujeito que está inserido em uma sociedade moralista e num lugar hostil e preconceituoso, enfrentando todos os dispositivos e técnicas de fabricação de um sujeito evidenciado por meio do seu discurso, e que apesar de se esforçar para conseguir o que deseja, não consegue vencê-la, pois suas práticas discursivas vão de encontro as práticas discursivas do sistema dominante do qual ele faz parte.

A leitura do romance é, portanto, ao mesmo tempo, uma representação de um espaço de controle do discurso e um lugar de infinitas possibilidades de produções de sentidos. É o movimento que pode constituir um lugar à subjetividade do/a leitor/a, no qual, por meio de seu conhecimento de mundo será capaz de variar sua produção de sentido; mas não com uma simples leitura, e sim uma leitura reflexiva e principalmente crítica. Exatamente o que fizemos a partir das ferramentas de Foucault e Pêcheux.

\section{LITERATURE AND SOCIETY: DISCURSIVE PRACTICES in Bom-Crioulo by Adolfo Caminha}

ABSTRACT: This work presents a discursive analysis of a literary work that explores extremely current topics, such as social and especially homophobic prejudices. We will examine in particular Amaro (Bom-crioulo), Aleixo and D. Carolina, characters from the creation O Bom-Crioulo, produced in 1895 by Adolfo Caminha, one of the main Brazilian authors of the Naturalist style. Specifically, we will highlight the discourses, power relations and subjectivity of the subjects represented here by the protagonists. Finally, we will show how these 
concepts shape society, how subjects of a particular time period are constructed by its discursive practices and the exercise of power relations, and since these are manufactured subjects, fabricated, constructed by these discursive practices, by the constituted powers, they thus become "useful" subjects to society. Such an approach is based on theoretical concepts by Michel Pêcheux and, especially, by Michel Foucault.

KEYWORDS: Discourse. Subject. Literature. Society.

\section{REFERÊNCIAS}

ABAURRE, Maria Luiza; PONTARA, Marcela Nogueira; FADEL, Tatiana. Português: Língua e literatura. Volume único. 2. ed. São Paulo: Moderna, 2003.

BRANDÃO, Helena Hathsue Nagazine. Introdução à análise do discurso. 2. ed. Campinas, SP: Editora da UNICAMP, 2004.

CAMINHA, Adolfo. O Bom-crioulo. São Paulo: Editora Martin Claret, 2003.

COURTINE, Jean-Jacques. O conceito de formação discursiva. In: . Análise do discurso político: o discurso comunista endereçado aos cristãos. São Paulo: EduFSCar, 2014. p. 69-96.

FOUCAULT, Michel. A arqueologia do saber. 7. ed. Rio de Janeiro: Forense Universitária, 2009.

. Vigiar e Punir: o nascimento da prisão. 20.ed. RJ, Petrópolis: Vozes, 1999.

. A ordem do discurso. 15 ed. São Paulo: Editora Loyola, 1996.

. Historia da sexualidade I: $A$ vontade do saber. 19. ed. Rio de Janeiro: Editora Graal, 1988.

. Historia da sexualidade II: $O$ uso dos prazeres. 12. ed. Rio de Janeiro: Editora Graal, 1984.

GREGOLIN, Maria do Rosário. Foucault e Pêcheaux na análise do discurso: diálogos e duelos. 2. ed. São Paulo: Claraluz, 2006.

PÊCHEUX, Michel. O discurso: estrutura ou acontecimento. 5. ed. Campinas, SP: Pontes Editores, 2008.

PÊCHEUX, Michel; FUCHS, Catherine. A propósito da análise automática do discurso: atualização e perspectivas (1975). In: GADET, Françoise; HAK, Tony (orgs.). Por uma 
Literatura e sociedade: as práticas discursivas na obra Bom-Crioulo de Adolfo Caminha

análise automática do discurso: uma introdução à obra de Michel Pêcheux. 4. ed. Campinas, SP: Editora da UNICAMP, 2010. p. 159-250.

Recebido em 11/01/2018.

Aprovado em 19/05/2018. 
